\title{
MICROBES AND MARKETS: WAS THE BLACK DEATH AN ECONOMIC
}

\section{REVOLUTION?}

\author{
Gregory Clark, UC-Davis \\ gclark@ucdavis.edu
}

\begin{abstract}
Did the Black Death have any effects on the medieval economy beyond what would be expected from the population losses? I test this by constructing measures of real wages, real land rents, and rates of return on capital from 1210 to 1500. These reveal first that there is no sign the Black Death had any effect on the efficiency of agriculture. Indeed efficiency changes little all the way from 1210 to 1500 . Second the return on capital did fall from $10 \%$ around 1300 to about 5\% by 1400, the biggest change in English history. But this decline seemingly began around 1300 , long before the Black Death, and so was probably unconnected. Third the measured efficiency of the agricultural sector in 1210 is little below the efficiency measured in the same way in 1600-49. Only after 1650 is there sign of growth in the efficiency of agriculture. The growth of the medieval economy in the thirteenth century, by implication, must have come from demographic factors and not technological advance.
\end{abstract}

Anyone writing a political history of England between 1066 and 1760 would certainly include a set of events pointed to as explaining how a feudal oligarchy in 1066 evolved into a limited democracy by 1760 . There would be debate about what events to include -1688 would be on everyone's list, but perhaps only some would include 1381. But any narrative would have some significant dates, some key turning points. A narrative history of this kind also implicitly includes the idea that these events made a difference, that other paths might have been followed, and that there is a story to be told about how we got from 1066 to 1760 .

When we turn to the economic history of 1066 to 1760 , though, the puzzle arises whether there are any specific dates or events that mattered. 1760 certainly seems different from 1066, but was it different because of discernable events, or because of 700 years of a drift so subtle that no person at any one time could feel the current? Those economic historians who hold to the idea of history as a narrative with specific events have focussed on the role of institutions or 
accident in shaping the economy. If institutions limit the performance of economies, and institutions can be changed by such forces as wars, politics, and religion then we can get the narrative back in. We can allow a role for accident and even personality. Opposed to this narrative view of economic history would be a kind of economic fundamentalism which would argue that in the end there is only one major determinant of economic growth which is the technological base of any society. This base shifted gradually and subtly in the years between 1066 and 1760, in a way that defies narrative. But this shift by increasing output per worker gradually shifted a lightly populated rural society of 1066, with perhaps only 2 million people, little long distance commerce and few towns, into a society of 6.5 million people with complex markets, much trade, and high levels of urbanization poised on the edge of industrialization by 1760. In this picture events such as the Black Death were mere wavelets on a gradually rising tide. Aside from producing some colorful gnashing of teeth and renting of garments by the afflicted, it was an inconsequential blip on the march to modernity.

The narrative impulse is found more in older histories. But interestingly while there is general agreement that 1066 to 1300 was as an era of expansion and economic growth, and 1300-49 a period of stasis or retrenchment, the narrative attached to the Black Death has diverged greatly. Postan saw the Black Death as compounding the economic weakness of the early fourteenth century, and as causing an economic recession that lasted until the sixteenth century when economic growth revived. ${ }^{1}$ Others, such as Usher, saw the plague as the final breakup of the institutional bonds that restricted the medieval economy, creating the possibilities for later economic growth. Direct cultivation of demesnes using labor services became unprofitable, bonded labor acquired new bargaining power in a labor scarce economy, and market forces were set loose to do their creative destruction. The total scale of the economy may 
have shrunk, but the level of efficiency with which resources were used increased under this new free market economy. ${ }^{2}$

Modern description of the Black Death period have been more nuanced, sometimes to the point of obscurity. Britnell, for example, surveying the commercialization of the economy from 1000 to 1500 notes that "change in the medieval period was slower than that of modern times, and yet its cumulative effects are not difficult to demonstrate."3 But he attributes no importance in this movement to any specific events. Over the years production technology and commercial organization improved slowly, but not in association with any specific events.

So did the Black Death matter? The debate about the effects of the Black Death, and indeed about the whole course of development between 1066 and 1500, stems in part from a lack of key pieces of information. Two basic things are reasonably well known about this period. The first is the level of population. Figure 1 shows a rough estimate of the level of population in the years 1210 to 1500 estimated as the consensus of a number of sources: Hallam (1988), Hatcher (1977), Ravi (1980), and Poos (1991). The second is the level of real wages. Figure 1 also shows on the same graph the real wages of carpenters from 1210 to 1500 , where the deflator is an index of agricultural prices.

The period 1210-1300 is regarded as a period of substantial economic growth, based on the population figures. This growth is often attributed to improvements in technology and commerce. ${ }^{4}$ But given the wage and population data of figure 1 the explanation for the growth of the medieval economy before 1300 could also be either higher fertility rates, or lower mortality rates. Suppose we assume that the birth rate was given at any time independently of

\footnotetext{
${ }^{1}$ See, for example, Postan (1938).

${ }^{2}$ Usher (1920), p. 132.

${ }^{3}$ Britnell (1993), p. 1.
} 


\section{Figure 1: Population and Wages, 1210-1500}

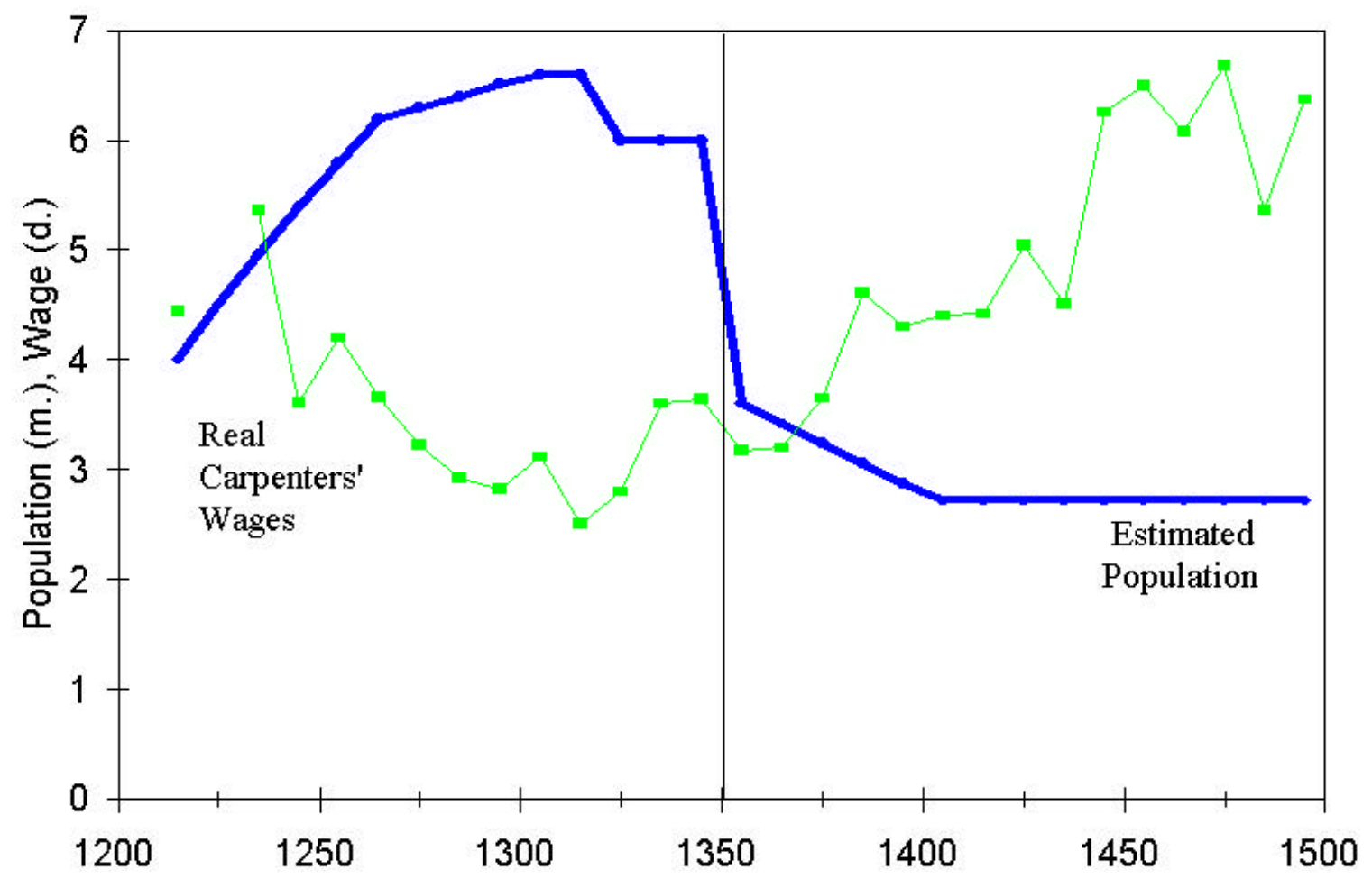

Notes: Carpenters wages are in pence per day, normalized to the prices of 1300-49 using an index of agricultural prices.

Sources: Nominal and real wages, Farmer (1988), Farmer (1991).

\footnotetext{
${ }^{4}$ Cameron (1989), p. 55, for example, states that the growth in part stemmed from innovations in agriculture such as the three course rotation and the replacement of ox traction by horses.
} 
the wage, that the death rate declined with higher wages, and that the technology was in fact unchanging, so that whenever population rose real wages fell. Then as shown in figure 2 the real wage $(\mathrm{w})$ in the long run will be determined as the wage where the birth rate (B) equals the death rate (D). At wages above this level births exceed deaths and population grows until the wage falls to this point. At wages below this level deaths exceed births and the population will fall till wages rise to the required level.

A rise in fertility will then cause a fall in the equilibrium real wage, and consequently population growth associated with lower real wages. This is what we observe for the period 1210 to 1300 . Thus it is possible that nothing of any significance happened to medieval technological and commercial efficiency in the years 1210-1500. That the only forces at play were those of demography and disease all the way from 1210-1500. First a period of high fertility and or low mortality, then a period of low fertility and or high mortality.

To determine whether there really was any change in the capacities of the medieval economy, either in the years 1210-1300, or in the years 1349-1500 we need to develop direct measures of the efficiency of the economy. The efficiency of any economy is simply the amount of output produced per unit of input of land, labor and capital. This can be measured in two different ways. The obvious way is to compare outputs with inputs. An equally good, but less obvious method is to compare the price of output with the payments to the inputs. Since the total of payments to the inputs has to equal the value of the output, in an efficient system where little input is used for each unit of output, the payments to inputs such as the wages of workers and the rent of land will be high. The appendix shows how efficiency can be measured in this way. There we show that, at least approximately, the efficiency of any market economy, relative to some initial period can be measured as 
Figure 2: The Effects of an Increase in Fertility on Wages and Population

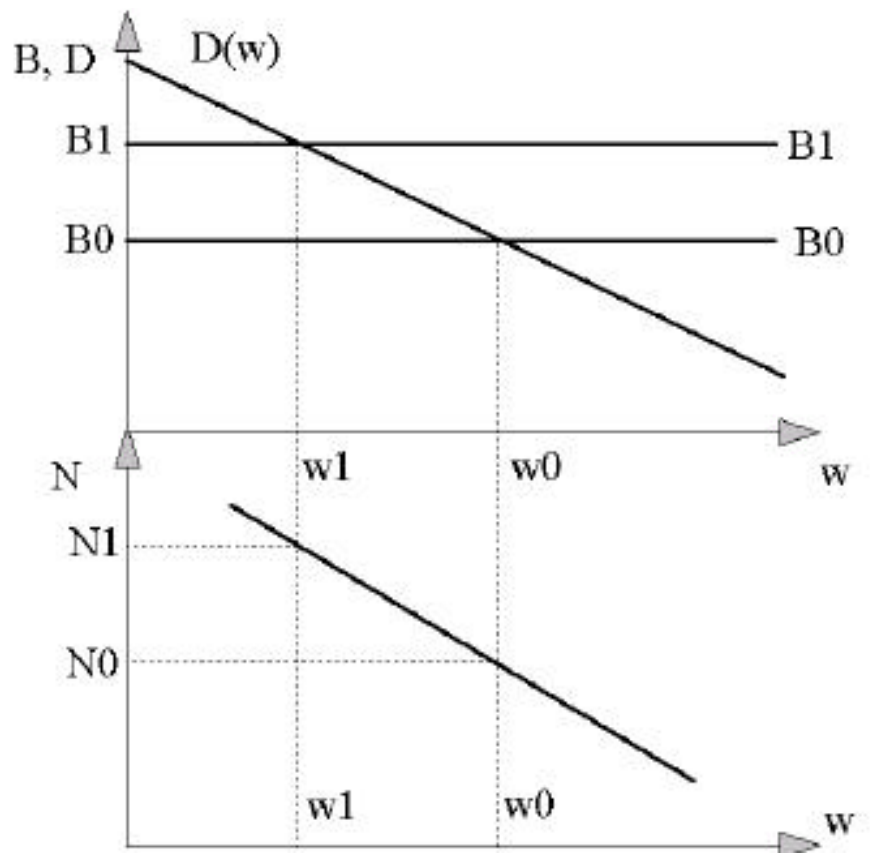




$$
\frac{E_{1}}{E_{0}}=\left(\frac{r_{1}}{r_{0}}\right)^{a}\left(\frac{w_{1}}{w_{0}}\right)^{b}\left(\frac{s_{1}}{s_{0}}\right)^{c}
$$

where $\mathrm{w}_{0}$ is the initial level of real wages, $\mathrm{w}_{1}$ the current level, $\mathrm{r}_{0}$ is the initial rate of return on capital, $\mathrm{r}_{1}$ the current rate, $\mathrm{s}_{0}$ is the initial level of real land rents, $\mathrm{s}_{1}$ the current level. $a, b$, and $c$ are the shares of capital, labor and land in the value of output.

Thus if we can construct measures of wages, prices, land rents, and the return on capital between 1210 and 1500 we can both estimate how much real productivity change accompanied the Black Death, why the population expanded so much in the years 1210 to 1300 , and also how the efficiency of the medieval economy compares with England on the eve of the Industrial Revolution. For reasons of data availability I restrict the examination here to the agricultural sector, but since this was the most important sector of the economy in throughout this period this is not too severe a limitation. 


\section{A Benchmark: What should happened from 1210 to 1500 with no efficiency change?}

To compare what we actually observe in the movement of wages, rents and returns with what actually happened we need to first construct a benchmark measure of what should have happened to wages, land rents and rates of return as a result of population changes in the years 1210-150 had there been no change in the efficiency of the economy. Consider, for example, the arrival of the Black Death in 1348-9. Since deaths from the initial onslaught of the plague in 1348 were in the order of $30-50 \%$ of the population, adjustment to the new equilibrium should have been immediate. By 1350 prices, wages, rents, and returns on capital should all have adjusted to be close to their new level. Thus what we expect to see from 1350 on is first higher real wages, since labor is now scarce relative to land. The amount by which real wages rise will depend, however, on the production technology and in particular on the degree to which it allows producers to substitute cheap land for expensive labor. Second a real land rents should fall, though again the size of the fall depends on the nature of production technology. The third important factor in production, capital, should see no change in its price, beyond a possible short period of adjustment. The real price of capital is the rate of return on investments such as land. ${ }^{5}$ The return on capital should depend on three things only in the long run - the time preference of individuals, which is how much they discount future consumption, the rate of growth of incomes per person on average, and the security of investments. If income is growing fast as in some modern economies, then everyone expects to have more income in future than now. This leads them to desire to consume some of that expected future income now, and in order to persuade at least some people to forgo current consumption the rate of return offered to those who save has

\footnotetext{
${ }^{5}$ Note that if the return on capital is high, this implies somewhat counter intuitively that goods such as land sell for a low price relative to their earning potential. In a society such as England in the late nineteenth century where capital was abundant, and its real return very low, this showed up in the land market as land selling for very large multiples of its annual rent, as much as 40 or 50 times the rent.
} 
to rise. Assuming that there was slow technological progress in both the pre and post plague economy, the expected rate of growth of income should be zero in both eras. Thus as long as intrinsic time preferences and security of property does not change, the rate of return on capital should also not change.

The amount by which wages rise and land rents fall depends on the structure of production in the economy, and in particular on how easy it is to substitute land and capital for labor in producing output. If there was only one production technique available in medieval agriculture, which used fixed proportions of labor, land, and capital, then the fall in population would have the biggest effect on the relative price of labor and land. If it was possible to easily shift technique and reduce labor requirements by adding land and capital, then the effects could be quite modest. All we know in practice is that the substitution possibilities lay somewhere between these two extremes.

The appendix lays out the technical details of this. The ease with which land, labor and capital can be substituted for each can be indexed by a number, $\sigma$, the elasticity of substitution. This can range from zero where the same bundle of resources have to be used whatever relative prices, to $\infty$, where the inputs can always be substituted for each other. If we, for example, assume that $\sigma=1$, and that population moved as portrayed in Figure 1, then real wages and real rents should follow the path shown in figure 3 if there was no change in the overall efficiency of the economy. Once we have the population numbers, and an estimate of the relative share of wages, land and capital in output then we can make a prediction of the movement of real wages, real rents and real returns. I calculate below that wages were $50 \%$ of the value of output in agriculture, and land 34\%, in the years 1300-49. That generates the predicted movement of real wages, land rents and returns from 1210 to 1500 if as expected the Black Death had no effect on 
efficiency in the economy. These movements are shown in figure 3. As can be seen on these assumptions the more than halving of the population level leads to only about a $40 \%$ rise in real wages and a $40 \%$ drop in real rents by 1400 . Most of the change takes place immediately. In the 1350 s wages are predicted to rise about $25 \%$, and real rents to fall by nearly $30 \%$ immediately after the first onslaught.

The path of real wages and rents shown in figure 3 is only one possible path. Table 1 shows how various different descriptions of the substitution possibilities from the technology of the medieval economy could lead to very different responses in wages and rents by the time population stabilized around 1400. Given the shares of land, labor and capital in the economy between 1300 and 1349, the plague could have caused a rise in wages anywhere from $0 \%$ to $86 \%$, and a fall in rents of anywhere from $0 \%$ to $100 \%$. While there is quite a possible range of wage rises, and rent falls, what we can see in table 1 is that if the efficiency of the economy does not change the rise in wages and the fall in rents should tend to equal each other. If wages rose by only $21 \%$, then rents should have fallen by $20 \%$. If wages rose by $40 \%$, rents should have fallen by $39 \%$. If wages rose by $81 \%$, rents should have fallen by $85 \%$.

The last two columns of Table 1 show the relative efficiency of our model economy measured after the Black Death compared to before the Black Death. By construction we have kept the efficiency constant. If the efficiency measures used in this paper were perfect in all circumstances they should show that the relative efficiency in 1400 stays at 1.00 . As can be seen if there is a high degree of substitution possible in the economy the geometric average works well as a measure of the efficiency, but if substitution is difficult this index will be misleading. An alternative index of efficiency is the arithmetic one which is just the weighted sum of relative real payments to factors, weighted by their average share in national income. 
Figure 3: Predicted Wages, Rents and Return on Capital, 1210-1500: $\sigma=1$

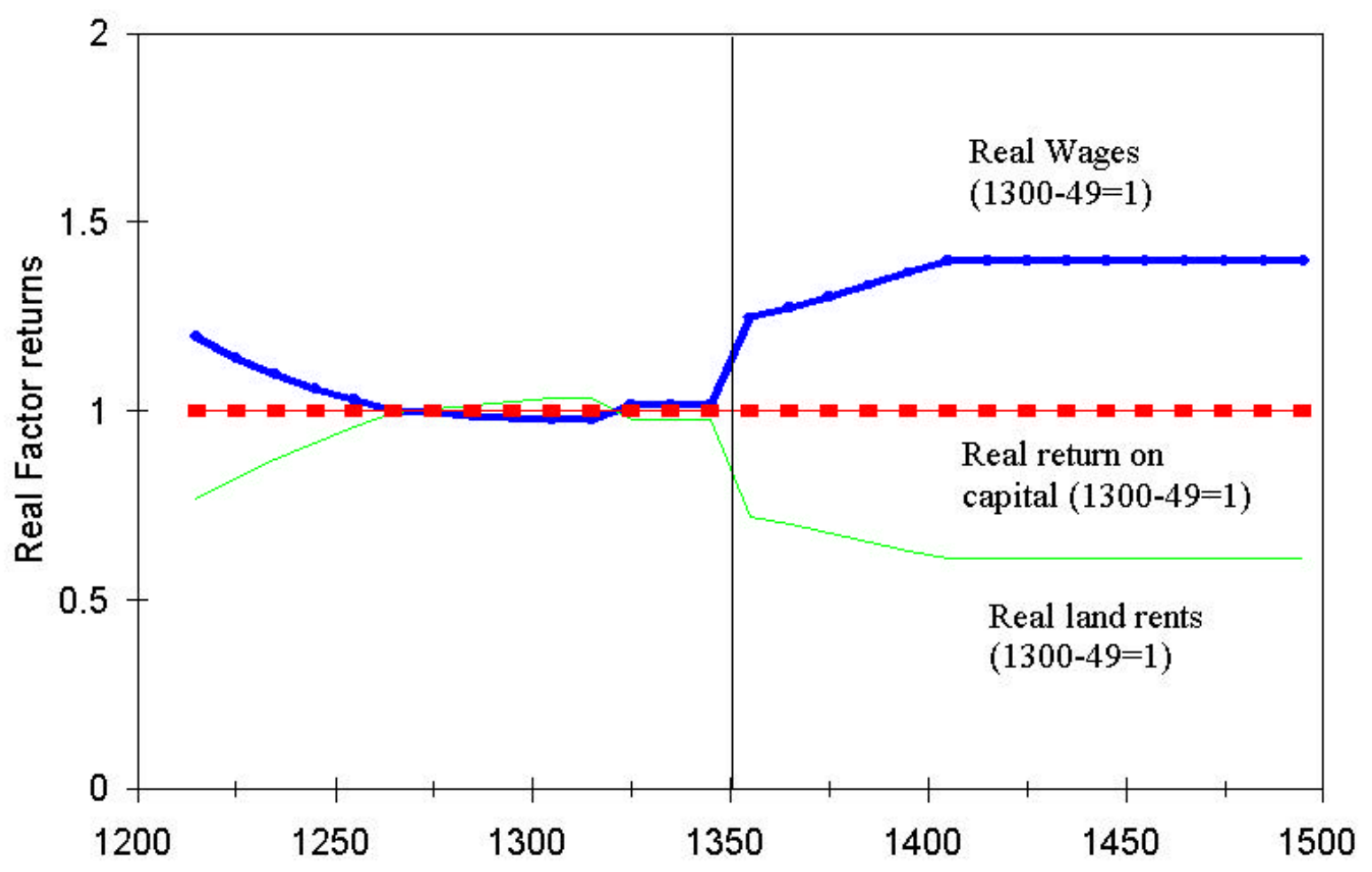


Table 1: The Expected Effect of the Black Death on Wages and Rents by 1400

\begin{tabular}{cccccc}
\hline $\begin{array}{c}\text { Elasticity } \\
\text { of } \\
\text { substitutio } \\
\mathrm{n}(\mathrm{s})\end{array}$ & $\begin{array}{c}\text { Relative capital } \\
\text { stock }(1300- \\
49=1)\end{array}$ & $\begin{array}{c}\text { Relative Wage } \\
(1300-49=1)\end{array}$ & $\begin{array}{c}\text { Relative Rent } \\
(1300-49=1)\end{array}$ & $\begin{array}{c}\text { Measured } \\
\text { efficiency, } \\
\text { weighted } \\
\text { average }\end{array}$ & $\begin{array}{c}\text { Measured } \\
\text { Efficiency, } \\
\text { geometric } \\
\text { average }\end{array}$ \\
\hline & & & & & \\
$\infty$ & 0.66 & 1.00 & 1.00 & 1.00 & 1.00 \\
4.00 & 0.65 & 1.11 & 0.90 & 1.02 & 1.01 \\
2.00 & 0.64 & 1.21 & 0.80 & 1.04 & 1.02 \\
1.33 & 0.62 & 1.31 & 0.70 & 1.05 & 1.01 \\
1.00 & 0.61 & 1.40 & 0.61 & 1.07 & 1.00 \\
0.80 & 0.60 & 1.48 & 0.53 & 1.08 & 0.98 \\
0.67 & 0.59 & 1.56 & 0.45 & 1.09 & 0.95 \\
0.50 & 0.56 & 1.68 & 0.32 & 1.11 & 0.88 \\
0.33 & 0.53 & 1.81 & 0.15 & 1.12 & 0.71 \\
0.25 & 0.51 & 1.86 & 0.07 & 1.11 & 0.54 \\
0.20 & 0.49 & 1.86 & 0.03 & 1.10 & 0.41 \\
0.17 & 0.48 & 1.84 & 0.01 & 1.08 & 0.31 \\
0.10 & 0.46 & 1.78 & 0.00 & 1.05 & 0.10 \\
0.00 & 0.44 & 1.68 & 0.00 & 1.00 & 0.00 \\
\hline
\end{tabular}

Note: The table is constructed assuming that the rate of return on capital remained unchanged after 1349 , and that the labor force in 1400 was 0.44 of the labor force of 1300-49. 


$$
\frac{E_{1}}{E_{0}}=a\left(\frac{r_{1}}{r_{0}}\right)+b\left(\frac{w_{1}}{w_{0}}\right)+c\left(\frac{s_{1}}{s_{0}}\right)
$$

Table 1 also shows the measured efficiency on this index, where by definition the efficiency should be 1.00 . As can be seen this index tends to overestimate relative efficiency, and does not work as well as the geometric index if there is a fair degree of substitutability between the inputs. If there is little substitutability this index while still overestimating relative efficiency is better than the geometric alternative.

Given that rents did not drop drastically after the Black Death it seems that the medieval economy did display a high degree of substitutability between inputs, so that the geometric efficiency index is best suited to measure relative efficiency over time. 


\section{Wages and Prices, 1210-1500}

For wages and prices I rely on information collected by David Farmer. The second to fourth columns of table 2 show by decade Farmer's estimates of the payment made for threshing one quarter each of wheat, barley and oats, for reaping and binding an acre of grain, and for mowing an acre of meadow. These are averaged and adjusted to day wages of agricultural workers in column 5 using a limited number of observations on actual day wages in the years 1300-49. These observations suggest an average day wage of agricultural workers in these years of $1.79 \mathrm{~d}$. per day outside the harvest season. For the last decade 1490-9 the agricultural wage is inferred from the wage of carpenters.

Agricultural prices are a weighted average of the prices of wheat, barley, oats, wool, cheese, and oxen, where the weights are $0.3,0.2,0.2,0.1,0.1,0.1$ respectively. This index is set to equal 1 on average for 1300-49.

Real wages are nominal wages deflated by agricultural prices, where again the index is adjusted to be 1 on average for the years 1300-49. Figure 4 shows real agricultural wages from 1210 to 1499 , comparing this with the path predicted by the population numbers in Figure 2, if the economy had an elasticity of substitution of 1 . As can be seen the rise in real wages is at the upper end of what might be predicted as a result of the plague by the mid fifteenth century. By the fifteenth century real agricultural wages average a $64 \%$ increase on their pre-plague level.

Interestingly while most of the wage effect should have been immediate, in the decades 1350-9 and 1360-9 real wages were slightly lower than their average for the years 1300-49. The response of real wages to the new lower level of population does not show up until the 1370s, almost a generation after the onset of the plague. This may be an artifact, however, created by the Statute of Laborers of 1351 which made paying wages higher than those of 1346-7 illegal. 
Table 2: Nominal and Real Agricultural Wages

\begin{tabular}{|c|c|c|c|c|c|c|}
\hline Decade & $\begin{array}{l}\text { Threshing per } \\
\text { bushel }\end{array}$ & $\begin{array}{l}\text { Reaping per } \\
\text { acre }\end{array}$ & $\begin{array}{l}\text { Mowing per } \\
\text { acre }\end{array}$ & $\begin{array}{l}\text { Implied } \\
\text { nominal day } \\
\text { wage }\end{array}$ & $\begin{array}{l}\text { Agricultural } \\
\text { price index }\end{array}$ & Real day wage \\
\hline 1210 & 3.28 & 3.54 & 3.06 & 1.07 & 0.59 & 1.07 \\
\hline 1220 & 3.65 & 4.37 & 3.38 & 1.23 & 0.71 & 1.03 \\
\hline 1230 & 3.53 & 4.84 & 3.51 & 1.28 & 0.66 & 1.15 \\
\hline 1240 & 3.59 & 4.61 & 3.51 & 1.26 & 0.75 & 1.00 \\
\hline 1250 & 3.71 & 4.77 & 4.12 & 1.36 & 0.79 & 1.02 \\
\hline 1260 & 3.53 & 4.67 & 4.62 & 1.38 & 0.82 & 1.00 \\
\hline 1270 & 3.72 & 4.61 & 3.98 & 1.33 & 1.06 & 0.74 \\
\hline 1280 & 4.00 & 4.81 & 4.28 & 1.41 & 0.91 & 0.92 \\
\hline 1290 & 4.55 & 4.90 & 4.65 & 1.53 & 1.07 & 0.85 \\
\hline 1300 & 4.73 & 5.45 & 4.97 & 1.64 & 1.00 & 0.97 \\
\hline 1310 & 4.82 & 6.65 & 5.46 & 1.82 & 1.34 & 0.81 \\
\hline 1320 & 5.27 & 6.40 & 5.82 & 1.89 & 1.20 & 0.93 \\
\hline 1330 & 5.32 & 6.16 & 5.56 & 1.84 & 0.96 & 1.14 \\
\hline 1340 & 5.38 & 5.87 & 4.95 & 1.75 & 0.90 & 1.15 \\
\hline 1350 & 6.00 & 7.22 & 6.32 & 2.11 & 1.27 & 0.98 \\
\hline 1360 & 6.46 & 8.17 & 6.96 & 2.33 & 1.44 & 0.96 \\
\hline 1370 & 7.56 & 9.22 & 7.58 & 2.63 & 1.24 & 1.25 \\
\hline 1380 & 7.77 & 9.14 & 7.60 & 2.65 & 1.00 & 1.57 \\
\hline 1390 & 7.69 & 8.73 & 6.79 & 2.51 & 1.07 & 1.39 \\
\hline 1400 & 8.59 & 9.54 & 7.04 & 2.72 & 1.15 & 1.40 \\
\hline 1410 & 8.37 & 9.95 & 6.85 & 2.71 & 1.09 & 1.47 \\
\hline 1420 & 8.27 & 9.21 & 6.95 & 2.64 & 1.03 & 1.52 \\
\hline 1430 & 9.16 & 9.48 & 6.46 & 2.72 & 1.22 & 1.32 \\
\hline 1440 & 9.16 & 10.45 & 6.35 & 2.80 & 0.89 & 1.86 \\
\hline 1450 & 9.95 & 9.93 & 6.72 & 2.88 & 0.90 & 1.89 \\
\hline 1460 & 10.59 & 10.00 & 6.58 & 2.95 & 0.96 & 1.82 \\
\hline 1470 & 10.92 & & 6.25 & 2.96 & 0.94 & 1.86 \\
\hline 1480 & & 10.00 & 6.13 & 2.49 & 1.15 & 1.28 \\
\hline 1490 & & & & $3.06^{*}$ & 0.89 & 2.04 \\
\hline
\end{tabular}

Notes: *Wage extrapolated from carpenters wages relative to 1300-49.

Source: Farmer (1988), pp. 734, 757, 768. Farmer (1991), pp. 444, 467, 471. 
Figure 4: Real Agricultural Wages 1210-1499

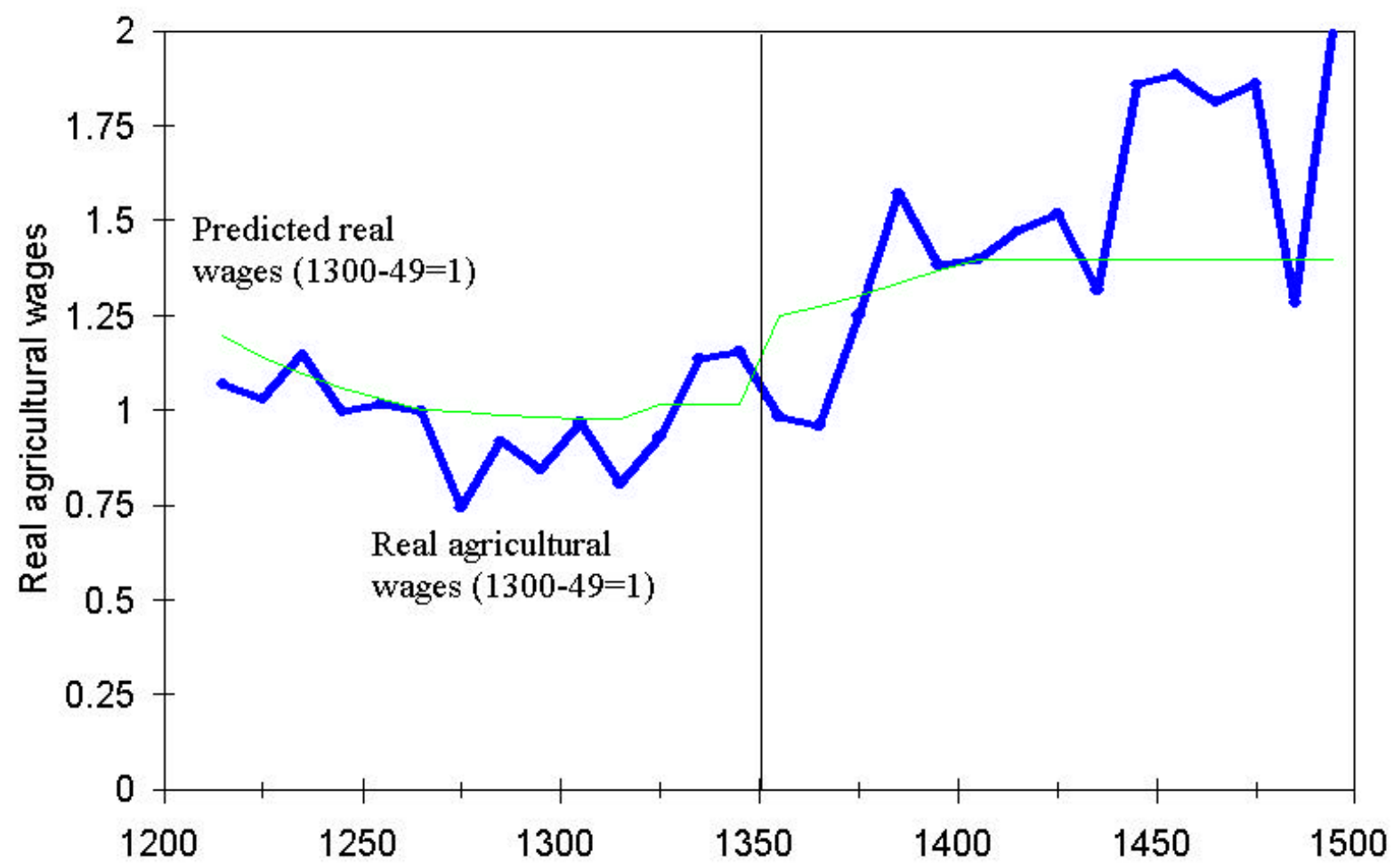

16 
The statute was probably widely evaded, but the evasion may have taken the form of allowing workers additional food on the job, or of incorrectly reporting lower wages than were actually paid. 


\section{Land Rental Values}

There are three potential sources of medieval land rental values, where by "rental value" what I mean is the amount the land would rent for if offered for rent on a competitive basis. The first of these is Inquisitions post mortem, valuations of estates by local juries on the death of the holder. The second is Manorial accounts and manor court records which record income from leases of parts of the demesne. This is the main source used here. But for the thirteenth century a third source, which suggests even higher land rental values than our demesne leases, are Cartularies, transcriptions of the property charters of religious houses and private families. These mainly show the prices of land, but this can be easily converted into implied rental values. 6

Each of these sources unfortunately has its limitations. And they also seem to give conflicting information as to the market rental values of land. Their temporal coverage is as follows:

IPM

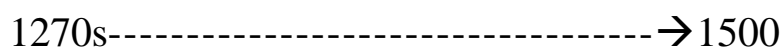

Manorial

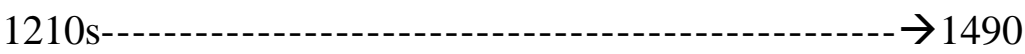

Charters

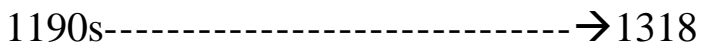

The IPMs have been used extensively by Campbell, Raftis and others to examine the relative values of land in different counties. These inquisitions record rental values for arable land particularly that are extraordinarily low, however. Poos, for example, in his study of Essex finds that in the period 1377-99 the IPMs value arable at $3.1 \mathrm{~d}$. per acre, the manorial accounts at 6-7 d. ${ }^{7}$ I shall show below that manorial accounts and charters consistently suggest land rental

\footnotetext{
${ }^{6}$ The cartularies also give leases, but often without stating what the consideration paid for the lease was, if any. ${ }^{7}$ Poos (1991), pp. 48-50.
} 
values greatly in excess of those recorded in the IPMs. I thus concentrate here on two other sources. ${ }^{8}$

On at least some years in many manors parts of the demesne would be leased out piecemeal at will or for a term of years. This leasing would be recorded in manorial accounts under the heading "firme" as opposed to "redditus assise." Sometimes these rents are recorded as such with no indication of the length of the lease or when it was formed. In other cases it may be recorded such as "leased for 10 years this being the second." Now land could be leased for a fixed rent per year, or it could be leased for an initial payment, an entry fine, followed by a lower annual rent. ${ }^{9}$ These entry fines if they existed are not recorded for specific holdings in the accounts, and thus the rents reported may understate the true rents per acre. ${ }^{10}$ If these entry fines were significant relative to the annual rents, and their size changed over time, this would potentially lead to a misleading index of rent movements from this source.

Utilizing a variety of sources I have constructed a data set of such land farms from 1210 to 1499 . The total number of individual plots observed is 2,997. But some manors produce many plots in a single year. Thus there were 48 plots observed in Hinderclay, Suffolk in the year 1400, but only one plot in Aldenham, Hertford in 1301. To avoid overweighting manors where we have a lot of observations I calculated for each manor in each year the total amount of land at farm and the total rent, constructing thus one observation for each manor in each year. If the sources indicated that land was farmed on a 10 year lease, I created an observation only for the first year of the lease even if the lease was recorded in multiple accounts. To control for

\footnotetext{
${ }^{8}$ The Inquisitions were still being conducted in the early seventeenth century, but the rental values reported for Wiltshire in 1625-30 in the inquisitions are less than 2/-per acre, at a time when average land rents in southern England exceeded 6/- per acre.

${ }^{9}$ The attraction of the fixed payment up front to the lessor was that it guaranteed against default by the rentor if it took time to eject someone for non-payment of rent.
} 
variations in the average value of land in different manors, and for potential variations in land measures, I also retained in the data set only those manors where land was observed in at least two years. What I estimate statistically is thus the average movement of rents across the decades in a set of manors controlling for differences in the level of rent in each manor so that changes in the composition of the data from decade to decade do not influence the results. ${ }^{11}$ This reduced the data to 52 manors with 917 observations in total.

Table 3 shows the surviving observations in this data set. First is listed the manor, then the estate to which it belonged, the county it lay in, the number of years in which there were observations, and finally the number of decades in which there were observations.

To estimate the average level of rent in each decade the following expression, in simplified form, was fitted to the data.

$$
\log (\text { rent / area })=\sum \beta_{i} \text { TYPE }_{i}+\sum \phi_{j} D E C_{j}+\sum \theta_{k} \text { Manor }_{k}+\varepsilon
$$

\footnotetext{
${ }^{10}$ Poos notes that entry fines were usually paid for farmed land on 10 Essex estates he examined, but does not indicate how he knows this. Davenport (1906) gives a set of six leases of a piece of demesne in the fifteenth century at Forncett, Norfolk. Only the last in 1497 has a fine, and this is small relative to the annual rent.

${ }^{11}$ There are substantial implied differences in the estimated level of rents across the 52 manors, with average rents on the Sussex manors of Battle Abbey showing up as 2-3 times the overall average. Rents on the Winchester manors consistently show up at 60-80\% of the average, except for Farnham in Surrey which shows higher than average rents.
} 
TABLE 3: MANORIAL LAND FARM DATA

\begin{tabular}{|c|c|c|c|c|}
\hline Manor & Estate & County & Years & Decades \\
\hline Aldenham & Westminster & Hertford & 5 & 3 \\
\hline Apuldrum & Battle Abbey & Sussex & 4 & 1 \\
\hline Ashford & Westminster & Middlesex & 5 & 3 \\
\hline Ashwell & Westminster & Hertford & 4 & 4 \\
\hline Bowthorpe & Crowland & Lincoln & 6 & 5 \\
\hline Bright Walton & Winchester & Berkshire & 2 & 2 \\
\hline Brotherhouse & Crowland & Lincoln & 14 & 5 \\
\hline Burnham & Battle Abbey & Sussex & 31 & 9 \\
\hline Casewick & Crowland & Lincoln & 15 & 6 \\
\hline Chaceley & Westminster & Worcester & 3 & 3 \\
\hline Crawley & Winchester & Hampshire & 51 & 10 \\
\hline Croyland & Crowland & Lincoln & 2 & 1 \\
\hline Cuxham & Merton & Oxford & 5 & 1 \\
\hline Deerhurst and Hardwicke & Westminster & Gloucester & 6 & 3 \\
\hline Downton & Winchester & Wiltshire & 83 & 21 \\
\hline Downton in the Isle & Ely & Cambridge & 12 & 6 \\
\hline Draught Accnt & Crowland & Lincoln & 3 & 2 \\
\hline Dunton Hall & Crowland & Lincoln & 7 & 4 \\
\hline Escher & Winchester & Surrey & 20 & 7 \\
\hline Farnham & Winchester & Surrey & 74 & 12 \\
\hline Fenhall & Crowland & Lincoln & 7 & 3 \\
\hline Forncett & & Norfolk & 85 & 11 \\
\hline Hinderclay & & Suffolk & 67 & 10 \\
\hline Holywell cum Needingworth & Ramsey & Huntingdon & 21 & 10 \\
\hline Icklesham & Battle Abbey & Sussex & 9 & 4 \\
\hline Islip & Westminster & Oxford & 2 & 1 \\
\hline Itchingswell & Winchester & Somerset & 6 & 6 \\
\hline Ivinghoe & Winchester & Buckingham & 16 & 4 \\
\hline Kelvedon & Westminster & Essex & 4 & 2 \\
\hline Knightsbridge & Westminster & Middlesex & 2 & 2 \\
\hline Langtoft & Crowland & Lincoln & 8 & 3 \\
\hline Launton & Westminster & Oxford & 3 & 2 \\
\hline Lullington & Battle Abbey & Sussex & 4 & 3 \\
\hline Meon & Winchester & Hampshire & 27 & 12 \\
\hline Monklade & Crowland & Lincoln & 5 & 2 \\
\hline Morden & Westminster & Surrey & 4 & 2 \\
\hline Nailsbourne & Winchester & Somerset & 17 & 7 \\
\hline Nomansland & Crowland & Lincoln & 11 & 5 \\
\hline Overton & Winchester & Hampshire & 13 & 9 \\
\hline Pershore and Wick & Westminster & Worcester & 2 & 2 \\
\hline
\end{tabular}




\begin{tabular}{lllll}
\hline Redgrave & & Suffolk & 55 & 12 \\
Rimpton & Winchester & Somerset & 6 & 5 \\
Sheep Account & Crowland & Lincoln & 10 & 4 \\
Staplegrove & Winchester & Somerset & 2 & 1 \\
Stevenage & Westminster & Hertford & 3 & 3 \\
Thetford & Crowland & Lincoln & 12 & 3 \\
Wargrave & Winchester & Berkshire & 39 & 11 \\
Wheathampstead & Westminster & Hertford & 2 & 2 \\
Wistowe & Ramsey & Huntingdon & 6 & 2 \\
Witney & Winchester & Oxford & 89 & 20 \\
Wycombe & Winchester & Buckingham & 22 & 11 \\
Wye & Battle Abbey & Kent & 6 & 5 \\
& & & & \\
All & & & 917 & 29 \\
& & & \\
\hline
\end{tabular}

That is I estimated the level of rent per acre (in logarithmic form) in each of the 29 decades allowing for differences in the type of land and the buildings associated with land with a set of TYPE variables, and for differences in the average level of rents across the 52 different manors used. Sometimes the accounts specified that land was arable, pasture, meadow, marsh, or "friscus" which was arable land turned to pasture use. Overall about $40 \%$ of land was described in such terms, the other $60 \%$ just being described as "land." In the estimation it was assumed that most of this "land" was arable since the overwhelming majority of land in medieval England seems to have been arable. Also sometimes land was leased with associated messuages, houses, cottages or "tofts." Further at least in the years after 1600 there is a tendency for land leased in larger parcels to let for less per acre, so that the total land area was also included in the regression. To allow for changes in the relative value of pasture, meadow, marsh and "frisc" after 1349 and the onset of the Black Death these type effects were estimated separated for the 
years before and after 1349 . This yielded 13 type variables in all. ${ }^{12}$ Table 4 shows the estimated effect of these variables. As can be seen, for example, meadow shows up as the most valuable land type as we would expect. Before the plague it is estimated as renting for an average of nearly five times the rental of "land". After the plague onset it rents for 2.75 times the rental of "land." "Frisc," arable turned as fallow or permanently to pasture is less valuable than "land" both pre and post plague. Plots with "messuages" "houses" "cottages" or "tofts" attached in general rent for more. Thus the estimation of rents in this way generally produces sensible results as far as these land types and attributes are concerned.

The shift in relative values of land after the plague is clear and statistically significant in the case of both pasture and meadow. Grassland becomes less valuable relative to arable. Indeed when we plot the average estimated value of arable and meadow by decade, as is done in columns 2 and 3 of table 5, we see surprisingly that in nominal terms arable and "land" show little decline in rental value after the plague, but the nominal value of meadow drops by about half. ${ }^{13}$ The reason this result is surprising is that arable land was the land on which most labor was employed, and where a rise in the cost of labor would hurt the land owners most. However, two processes seem to have been at work which could explain this result. First after the plague more land was used as pasture and meadow. Presumably the land transferred was not as valuable as the land used as meadow before the plague, depressing rents. And the land kept as arable would be the land most productive in this use. Secondly there is some sign that the price of grains rose relative to the price of pasture products: after 1349 there was about a $25 \%$ rise in the relative price of grains.

\footnotetext{
${ }^{12}$ It would also have been possible to estimate specific arable and meadow values for each decade, but these estimates would have such high associated sampling errors that they would be largely meaningless.

${ }^{13}$ These estimates are for 1 acre plots with no associated buildings, but the area effect on rent is so small in this case that a 100 acre plot would have rents equal to $84 \%$ of these ones.
} 
TABLE 4: THE ESTIMATED EFFECT OF THE CONTROL VARIABLES

\begin{tabular}{llll}
\hline Variable & Coefficient & Standard Error & $\begin{array}{l}\text { Relative rent of such land } \\
\text { compared to "land" }\end{array}$ \\
& & & \\
\hline & $-0.0387^{* *}$ & 0.0129 & \\
Larea & $-0.370^{* *}$ & 0.134 & 0.69 \\
Fraction "frisc" pre plague & $-0.154^{*}$ & 0.069 & 0.86 \\
Fraction "frisc" post plague & $0.483^{* *}$ & 0.134 & 1.62 \\
Fraction pasture pre plague & 0.071 & 0.115 & 1.07 \\
Fraction pasture post plague & $1.603^{* *}$ & 0.282 & 4.97 \\
Fraction meadow pre plague & $1.008^{* *}$ & 0.111 & 2.74 \\
Fraction Meadow post plague & -0.018 & 0.622 & 0.98 \\
Fraction marsh pre plague & $0.826^{* *}$ & 0.243 & 2.29 \\
Fraction marsh post plague & & & \\
& $2.188^{*}$ & 0.972 & 8.92 \\
Messuages per acre & $1.408^{*}$ & 0.687 & 4.09 \\
Houses per acre & 1.042 & 2.210 & 2.83 \\
Cottages per acre & 1.084 & 2.277 & 2.96 \\
"Tofts" per acre & & & \\
\hline
\end{tabular}


TABLE 5: ESTIMATED AVERAGE RENTS PER ACRE BY DECADE

\begin{tabular}{|c|c|c|c|c|c|}
\hline Decade & $\begin{array}{l}\text { Number of } \\
\text { manors }\end{array}$ & $\begin{array}{l}\text { Arable and "land" rents } \\
\text { d./acre }\end{array}$ & $\begin{array}{l}\text { Meadow rents } \\
\text { d./acre }\end{array}$ & $\begin{array}{l}\text { Average rent of } \\
\text { all land } \\
\text { d./acre }\end{array}$ & $\begin{array}{l}\text { Real Rent (all) } \\
(1300-49=1)\end{array}$ \\
\hline 1210 & 5 & 7.7 & 38.5 & 8.8 & 1.48 \\
\hline 1220 & 7 & 7.0 & 34.8 & 7.9 & 1.12 \\
\hline 1230 & 7 & 7.3 & 36.2 & 8.3 & 1.25 \\
\hline 1240 & 8 & 9.3 & 46.4 & 10.6 & 1.41 \\
\hline 1250 & 8 & 8.6 & 42.6 & 9.7 & 1.23 \\
\hline 1260 & 12 & 8.3 & 41.4 & 9.4 & 1.15 \\
\hline 1270 & 12 & 6.9 & 34.2 & 7.8 & 0.73 \\
\hline 1280 & 14 & 7.7 & 38.2 & 8.7 & 0.96 \\
\hline 1290 & 13 & 8.6 & 42.5 & 9.7 & 0.90 \\
\hline 1300 & 20 & 9.2 & 45.6 & 10.4 & 1.04 \\
\hline 1310 & 19 & 9.3 & 46.4 & 10.6 & 0.79 \\
\hline 1320 & 18 & 10.3 & 51.0 & 11.6 & 0.97 \\
\hline 1330 & 20 & 9.8 & 48.6 & 11.1 & 1.15 \\
\hline $1340 *$ & 20 & 8.4 & 41.8 & 9.5 & 1.06 \\
\hline $1350 *$ & 12 & 8.2 & 22.6 & 9.4 & 0.74 \\
\hline 1360 & 12 & 9.2 & 25.1 & 10.4 & 0.72 \\
\hline 1370 & 10 & 8.6 & 23.6 & 9.8 & 0.79 \\
\hline 1380 & 13 & 9.6 & 26.2 & 10.9 & 1.09 \\
\hline 1390 & 14 & 8.2 & 22.4 & 9.3 & 0.87 \\
\hline 1400 & 9 & 7.8 & 21.4 & 8.9 & 0.77 \\
\hline 1410 & 9 & 7.5 & 20.7 & 8.6 & 0.79 \\
\hline 1420 & 8 & 6.9 & 18.8 & 7.8 & 0.76 \\
\hline 1430 & 8 & 7.4 & 20.2 & 8.4 & 0.68 \\
\hline 1440 & 9 & 7.1 & 19.4 & 8.0 & 0.90 \\
\hline 1450 & 8 & 7.1 & 19.4 & 8.1 & 0.89 \\
\hline 1460 & 3 & 7.2 & 19.9 & 8.3 & 0.86 \\
\hline 1470 & 6 & 5.4 & 14.8 & 6.2 & 0.65 \\
\hline 1480 & 2 & 6.3 & 17.2 & 7.2 & 0.62 \\
\hline 1490 & 2 & 6.2 & 17.0 & 7.1 & 0.80 \\
\hline
\end{tabular}

Notes: The average rents in each case are averages across the rent levels in all the 52 manors.

*1340-48 and 1349-59. 
Given these estimates we can estimate the average rental value per acre in each decade by assigning land in proportion to arable, meadow, pasture, and frisc. In the data I have the overall proportions before 1349 are $68 \%$ "land" or arable, $0 \%$ frisc, $1 \%$ pasture, and $26 \%$ meadow. After 1349 the proportions are $78 \%$ "land" or arable, $2 \%$ frisc, $8 \%$ pasture, and $10 \%$ meadow. But these proportions are heavily influenced by the type of manors which happened to be included in each period. So instead for weighting I rely on data from the IPM reported in Campbell et al. (1992) and Poos (1991). ${ }^{14}$ This suggests a weighting before 1349 of arable at $88 \%$, pasture at $6 \%$, and meadow at $6 \%$, but after 1349 of arable $68 \%$, frisc $2 \%$, pasture $18 \%$, and meadow $12 \%$. With these weightings we get the implied average nominal and real rents shown in the fourth and fifth columns of table 5. Since these estimates are based on a small number of manors they are subject to sampling error.

Figure 5 portrays estimated average real rents by decade, compared with what we would expect given the population trends. The decline in real rents is surprisingly small given the decline in population, and the large rise in real wages. If these numbers are correct there would have been little real loss to landowners consequent on the plague. Land let on customary terms before the plague which were below real market rental values would continue to supply these payments, since the market rental value fell relatively little. Demesne land directly cultivated should have brought in incomes not greatly below those of the pre-plague level, even when leased to farmers. The wage gains after the onset of the plague were seemingly not mainly just a transfer of income from land owners. These modest real rent declines after the plague also suggest that it is unlikely that there was large scale abandonment of cultivation on marginal lands.

\footnotetext{
${ }^{14}$ Poos (1991), p. 47 gives the proportion of arable, pasture, and meadow in Essex before and after the Black Death.
} 
Figure 5: Actual and Predicted Real Land Rents, 1210-1500

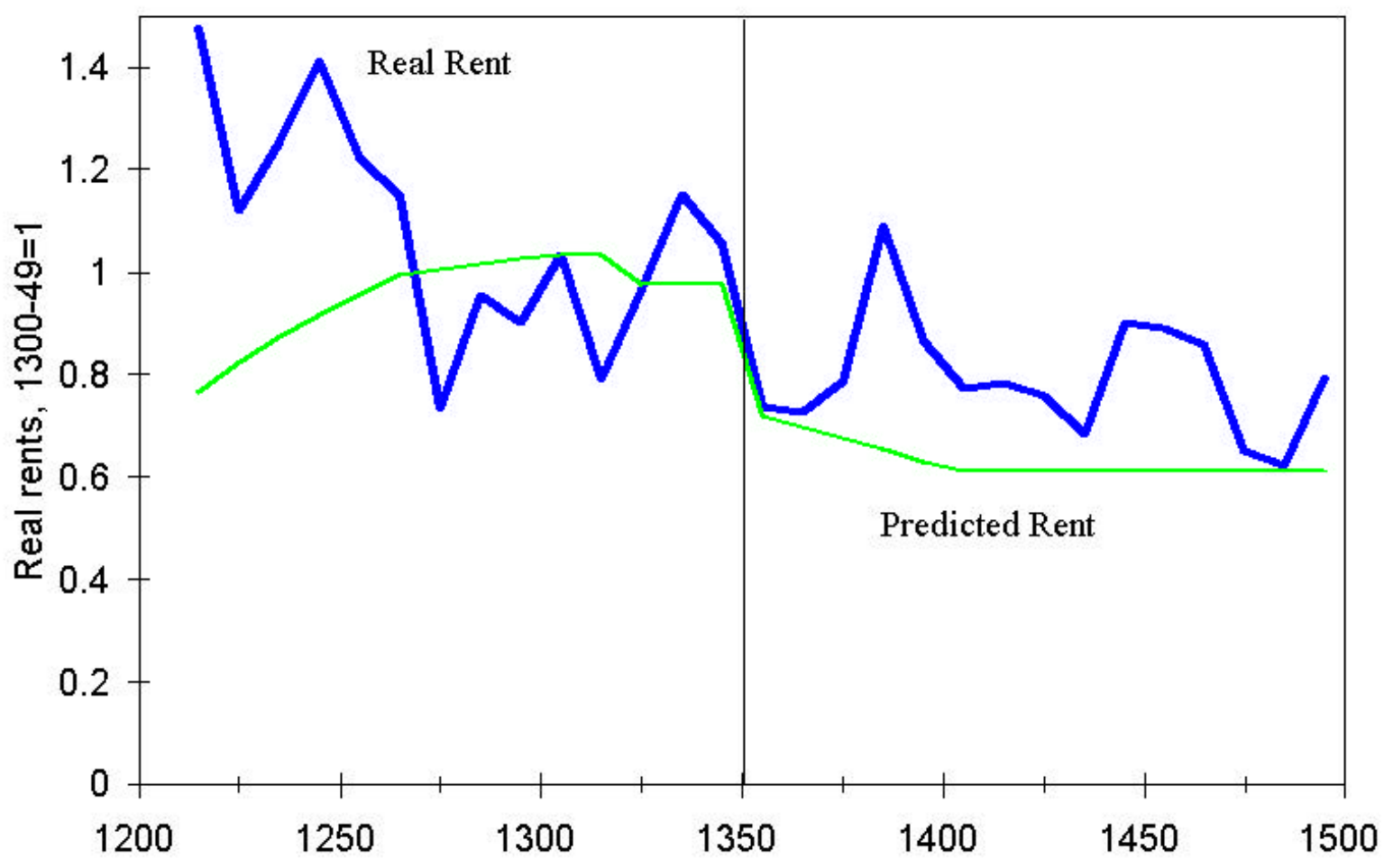




\section{Medieval Rates of Return on Capital}

There seems to be only one feasible source of information on medieval rates of return on capital and this is from the cartularies constructed by religious houses and secular land owners. A cartulary was a collection of copies of documents transferring land and other property by gift or by sale to a religious house, compiled to record the various property holdings of the institution or family. Over the years many of these cartularies have been printed.

One property transferred in these deeds was rent charges - payments of specified sums of money in perpetuity secured by houses or land. Where the deed specifies a "gersuma," an amount of money paid for the transfer, the implied rate of return on the capital so invested is just the rent divided by the payment. Transfers deeds from the 1170 s up until the 1310 s often contain statements of the amounts paid for the rent charge. After this the deeds general contain no statement of the amount paid for the rent.

A problem with these deeds as a source is that the transfer may not reflect the full price paid for the rent. The medieval legal system apparently countenanced later claims by the spouse and the heirs of someone selling property. So sometimes the deeds of institutions or families include also deeds from these potential claimants renouncing their claims to the property. If only some of these deeds survive to be copied into the cartulary at a later date, then only part of the full purchase price of the property will be recorded. In this case the apparent rate of return on the purchase will be inflated.

A second problem is that many of the surviving transactions are transfers of rents to religious institutions. If there is an element of gift in the transfer again the purchase price will be depressed and the return inflated. If there is an element of charity the price may be inflated and 
the return correspondingly depressed. We can check on this possibility, however, by comparing the returns on transfers of rents between lay parties and between lay and religious.

Figure 6 shows the range of years purchase (the inverse of the rate of return, and the way prices were in fact calculated) for all the transfers recorded before 1300 when the median rate of return as we shall see seems to have been stable at around $10 \%$ or 10 years purchase. As can be seen there is a considerable range in the years purchase paid, ranging from 2 to 53. But almost half the transactions involved a years purchase of between 9 and 11. Some of this variation in the years purchased used seems just to have stemmed from computational convenience. If a rent is denoted in pence only, then if it is capitalized at 12 years purchase the sum required is just the same numbers of shillings. Similarly if a rent is denoted in shillings only, then if it is capitalized at 13.33 years purchase the capital sum in just the same in marks. If the rent is measured in marks only there is no particular years purchase that will make the capital sum easy to calculate. Table 6 shows the years purchase used when the rent was denoted in pence only, in shillings only and in marks only in the years before 1300 .

Table 6: Years purchased used and the denomination of rent charges before 1300

\begin{tabular}{lcccccc}
\hline Rent type & Number & 9 & 10 & 12 & 13.33 & Other \\
\hline Pence only & 137 & 7 & 17 & $\mathbf{2 2}$ & 3 & 88 \\
Shillings only & 106 & 7 & 27 & 0 & $\mathbf{1 9}$ & 53 \\
Marks only & 19 & 7 & 4 & 2 & 0 & 6 \\
\hline
\end{tabular}


Figure 6: The Distribution of Years Purchase before 1300

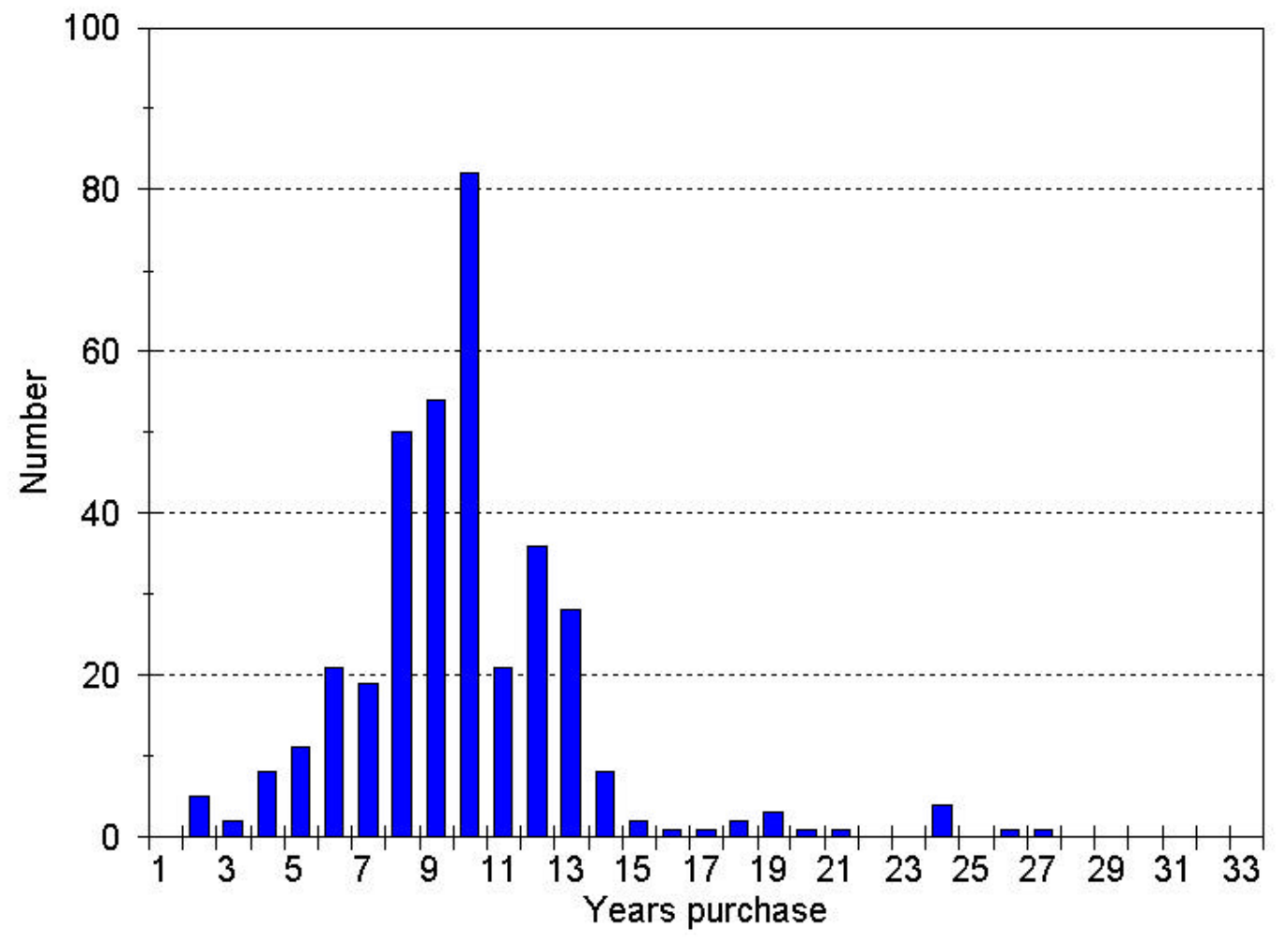

Note: Two observations with years purchase of 48 and 53 are not shown. There are 364 observations in all 
Table 7 lists the number of rent charge sales where a consideration was recorded from 40 cartularies by decade, with the limitation that the consideration had to be at least two times the rent transferred. Where a range of years was given as the possible date for the deed the midpoint year was used to assign it to a decade. The total number of calculated returns is 384 . The table also shows the median rate of return implied by these transfers for each decade. The median rather than the mean is used to avoid over weighting the problematic transfers with very low and very high consideration prices. As can be seen the median rate of return is typically about $10 \%$ for the years before 1300. This is true also if we restrict ourselves to transfers between lay parties where there might be less likelihood of a gift by one party or the other. By the 1370s all five transactions imply a rate of return on capital of only $5 \%$. Other evidence for the early 1400 s confirms that by then the typical return from rent charges was only $5 \%$. Thus sometime between 1300 and 1400 the rate of return earned by capital seems to have roughly halved. ${ }^{15}$

The evidence from the 11 transfers between 1300 and 1348 is that some of this decline had already occurred before the plague struck. Thus the median return in these years was $8.1 \%$, which is lower than in any of the previous 13 decades with evidence on returns. The chance that in choosing 11 returns from the sample of returns seen in the years before 1300, that at least 6 would be below $8.2 \%$ or less can be calculated at 0.5 in $100 .{ }^{16}$ Thus we can say with better than $99 \%$ confidence that the rate of return was lower in the years 1300-49 than before. Thus there is clear sign that the rate of return had begun to fall already by 1300 long before the onset of the

\footnotetext{
${ }^{15}$ Thrupp (1948), notes that investing in real property "In the mid-fourteenth century it was possible to expect from 6 to 8 per cent; in the fifteenth century the market price of country property rose, pushing the returns down to about 5 per cent on investments." (pp. 122-3). Bean (1991) notes that in the mid thirteenth century the rate of return earned on land was $10 \%$, but a will of 1375 assumes a return of only $7.5 \%$, and by the mid fifteenth century $5 \%$ was the norm.

${ }^{16}$ Only 63 out of 370 observations before 1300 were of returns equal to or below $8.2 \%$. From the binomial distribution the chance of drawing 11 returns from such a distribution and getting at least 6 of them equal or below $8.2 \%$ is only 0.5 in 100 .
} 
Black Death, and that the fall in returns on capital between 1300 and 1400, dramatic as it was, had no connection with the Black Death.

The fall in rates of return from above $10 \%$ in 1300 to $5 \%$ by 1400 was the most significant change in real rates of return in English history. Rates of return on rent charges did fluctuate somewhat after 1400 , climbing back up to rates of $6 \%$ in the early seventeenth century, and eventually falling just below $4 \%$ in the late nineteenth century. But no period witnessed return on capital that ever again equaled those of the thirteenth century. The decline in rates of return should be associated with significant increases in income. With a reasonable ability to substitute capital for labor and land in the economy a fall in the real return on capital will imply much greater amount of capital is used per person, and consequently output per person will increase. Goods which embody a lot of capital such as housing and roads become much cheaper relative to their replacement costs. Consequently at the same level of income workers in 1400 could consume much more housing space than in 1300 . If a house, for example, costs $100 /-$ to construct, then its annual rental cost will have to include 10/- in 1300 to cover just the capital embodied in the construction. By 1400 this element of rental costs would have fallen to 5/- with the lower rates of return. In areas such as the countryside where the main rental cost of housing would be construction costs (as opposed to site rental values as in the center of cities), housing consumption per capita should thus have increased sharply by 1400 as a result of both higher labor incomes, and of lower rental costs. Similar arguments will apply to a whole range of improvements to the infrastructure such as roads, mill ponds, weirs, and land drainage.

Why 1300 should be such a significant turning point in capital markets in England is mysterious. 
Table 7: The Rate of Return from Rent Charge Conveyances

\begin{tabular}{|c|c|c|c|c|}
\hline Decade & All transfers & Median Return & $\begin{array}{l}\text { Transfers between } \\
\text { Lay }\end{array}$ & Median return \\
\hline 1170 & 8 & 9.2 & 0 & - \\
\hline 1180 & 4 & 10.5 & 0 & - \\
\hline 1190 & 6 & 9.7 & 3 & 9.9 \\
\hline 1200 & 24 & 8.9 & 6 & 9.2 \\
\hline 1210 & 19 & 10.5 & 2 & 11.4 \\
\hline 1220 & 44 & 10.0 & 17 & 10.0 \\
\hline 1230 & 44 & 10.2 & 11 & 9.9 \\
\hline 1240 & 52 & 10.0 & 19 & 10.0 \\
\hline 1250 & 51 & 10.0 & 14 & 10.0 \\
\hline 1260 & 36 & 10.0 & 11 & 11.6 \\
\hline 1270 & 42 & 10.7 & 18 & 11.9 \\
\hline 1280 & 22 & 10.8 & 16 & 10.6 \\
\hline 1290 & 11 & 10.0 & 7 & 10.0 \\
\hline 1300 & 8 & 8.2 & 6 & 7.9 \\
\hline 1310 & 2 & 8.0 & 2 & 8.0 \\
\hline 1340 & 1 & 7.5 & 0 & - \\
\hline 1370 & 1 & 5.0 & 0 & - \\
\hline 1440 & 1 & 5.0 & 0 & - \\
\hline 1530 & 1 & 5.0 & 0 & - \\
\hline 1540 & 1 & 5.0 & 1 & 5 \\
\hline 1560 & 1 & 5.0 & 0 & - \\
\hline
\end{tabular}

Sources: See the list of printed cartularies in the bibliography. 


\section{Charters and Land Rental Values}

The charters contain many references to transfers of land and houses. Thus they contain references to the purchase prices of land, with the same caveats as for rent charges that the price may be understated because other parties quitclaimed, but their quitclaims did not survive to be recorded in the cartulary. Given that we know from 1560 to 1912 that the return on rent charges tended to be quite close to the return earned on land, we can use the interest rate earned on rent charges to infer the rental value of this land. ${ }^{17}$

I have not had time to explore these transfers in any great depth, but a brief survey of some cartularies listing properties in a variety of counties is reported in table 8 . The table quotes the median price per acre of land without buildings by county, and overall. Median prices, as opposed to means, are again quoted because of the potential problem of outliers.

\section{Table 8: Median Land Prices in Charters, 1200-1318}

\begin{tabular}{lllll}
\hline County & $\begin{array}{l}\text { Number of } \\
\text { Observations }\end{array}$ & $\begin{array}{l}\text { Median Price per } \\
\text { Acre (s.) }\end{array}$ & $\begin{array}{l}\text { Number of } \\
\text { observations of } \\
\text { plot }>=5 \text { acres }\end{array}$ & $\begin{array}{l}\text { Median Price } \\
\text { per Acre (s.) }\end{array}$ \\
\hline Berks, Bucks, & 32 & 14.2 & 3 & 10.0 \\
$\begin{array}{l}\text { Oxford } \\
\text { Derby }\end{array}$ & 11 & 5.7 & & 5.1 \\
Kent & 22 & 20.8 & 4 & 11.6 \\
Lincoln & 18 & 37.3 & 4 & 36.0 \\
Norfolk & 18 & 22.2 & 11 & 4.0 \\
Northampton & 27 & 20.0 & 3 & 6.0 \\
Somerset & 6 & 11.7 & 4 & 12.6 \\
Suffolk & 30 & 21.2 & 1 & 16.0 \\
All & 164 & 19.9 & 5 & \\
& & & 35 & \\
\hline
\end{tabular}

\section{Sources:}

\footnotetext{
${ }^{17}$ For this evidence see Clark (1998).
} 
These median prices suggest, based on the rate of return on rent charges, that land rental values were high in the thirteenth century. A median price of nearly 20/- per acre suggests a rental value of $24 \mathrm{~d}$. per acre. Since the plots involved in these transfers were on average small, being only a few acres on average, I also report median prices per acre on plots of 5 or more acres. This price is considerably lower, but still implies a median rental value of $15 \mathrm{~d}$. per acre. ${ }^{18}$ The manorial sources suggest an average rental value of $9 \mathrm{~d}$. per acre in the thirteenth century. Thus the charter evidence suggests that rental values if anything must have been higher in the thirteenth century than suggested by manorial accounts.

\section{The Overall Efficiency of the Medieval Agrarian Economy}

Now that I have constructed measures of wages, prices, land rental values, and the return on capital, I can estimate the efficiency of the agrarian economy overall. Figure 7 shows the efficiency calculated as the geometric average of the real payments to the factors. As can be seen, within the margins of error imposed by the limited amount of data, it looks as though through the long period or nearly 300 years from 1210 to 1500 there is no sign of any substantial change in the efficiency of the economy. The population growth of 1210 to 1290 or 1315 was apparently not the product of any improved efficiency of the economy, and consequently was more likely the product of a change in birth or death rates. There is no sign that the Black Death caused any major upward or downward move in efficiency. It did not radically change the direction of the economy.

When I write that we have estimated the efficiency of the agrarian economy, I should be clear that we are estimating the efficiency of that part of the economy which was employing land

\footnotetext{
${ }^{18}$ This effect may be very strong since we are not controlling for land use here. Meadow, which tended to be the
} 
Figure 7: The Efficiency of the Agrarian Economy, 1210-1500

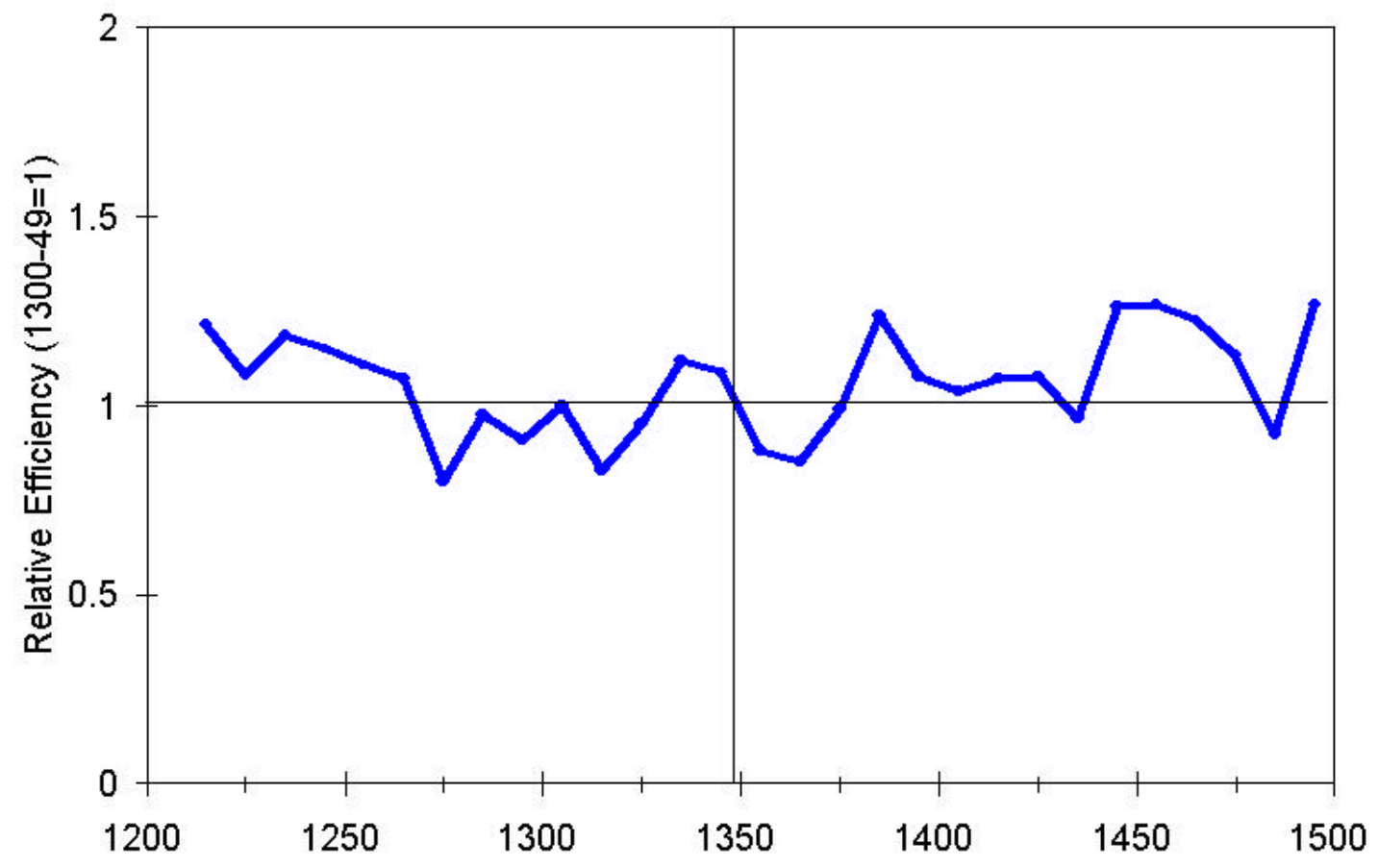

most valuable land, was often held in small units. 
that paid money rents. The efficiency of peasant occupiers of customary land, and of landlords directly cultivating land, might have been much lower than this, but only if both these groups were willing to accept lower income from cultivating their own land than they could have obtained by leasing it out. We are thus in some sense estimating the efficiency of the best practice cultivators, those who had to compete for their land in a competitive rental market. But if there was not too much difference between these cultivators and the rest of the land occupiers, the message we get is that there was essentially a 300 year period of stasis in medieval agriculture. No progress had been made by 1500 , and the Black Death certainly did not alter the efficiency of the commercial sector in agriculture.

Since we have constructed measures of wages, rents and the return on capital for the medieval economy, it is possible to also examine how efficient the medieval agrarian economy was relative to the agricultural sector in England in the years 1580-1869 using data from other sources that also generate estimates of the return on capital, real wages and real rents. Figure 8 shows wages and land rents measured in terms of the average price of agricultural output from 1210 to 1870 , as well as the real rate of return on capital. There is no difficulty linking up the series on wages and return on capital. But while each land rent series probably reports relative rents reasonably well for its period, linking them is a little problematic since they were constructed in different ways. The early series gives land rents net of tithe on land without buildings. The later series gives again land rent net of tithe, but the level is fixed on the assumption that the average rent of farmland without buildings in the 1860s would 26/-, which may be incorrect. ${ }^{19}$ As can be seen from 1580 to 1870 there was a very significant rise in real

\footnotetext{
${ }^{19}$ I have also not made any allowance for tithe, which was probably higher relative to rent in the middle ages, and for local taxes which fell on land.
} 
land rents, well above medieval levels as measured in the prices of agricultural output. But real wages increased little, at least as measured in terms of farm output, and capital returns fell.

Figure 9 shows what these numbers imply for the movement of the productivity of English agriculture from 1210 to 1870, where the weights used throughout are $40 \%$ for land and labor, and $20 \%$ for capital. Since these weights are a little different than those used for the medieval period the productivity movement in figure 9 will be slightly different than that in figure 7 for the years 1210-1500. As can be seen these numbers suggest that productivity was essentially flat all the way from 1210 to 1650 , with a total suggested gain in this 440 year interval of less than $10 \%$. Around 1650 begins a slow upward march of productivity which by the 1860 s had increased output per unit of input over those 210 years by about $50 \%$ from its level in 1600-49. This suggests several things. The first is that it is hard to find any specific institutional reasons for the eventual advance of agricultural productivity. The ending of most of the important feudal institutions occurred long before there was any productivity response in agriculture. The second is that with a metric of productivity alone the Black Death is quite invisible in the historical record. The shock was apparently absorbed relatively easily with little long term impact. Had the Black Death not occurred, and population never suffered its long decline, we would seemingly have been at the same place in 1600 . 
Figure 8: Rate of Return, Real Wage and Real Rents, 1210-1870

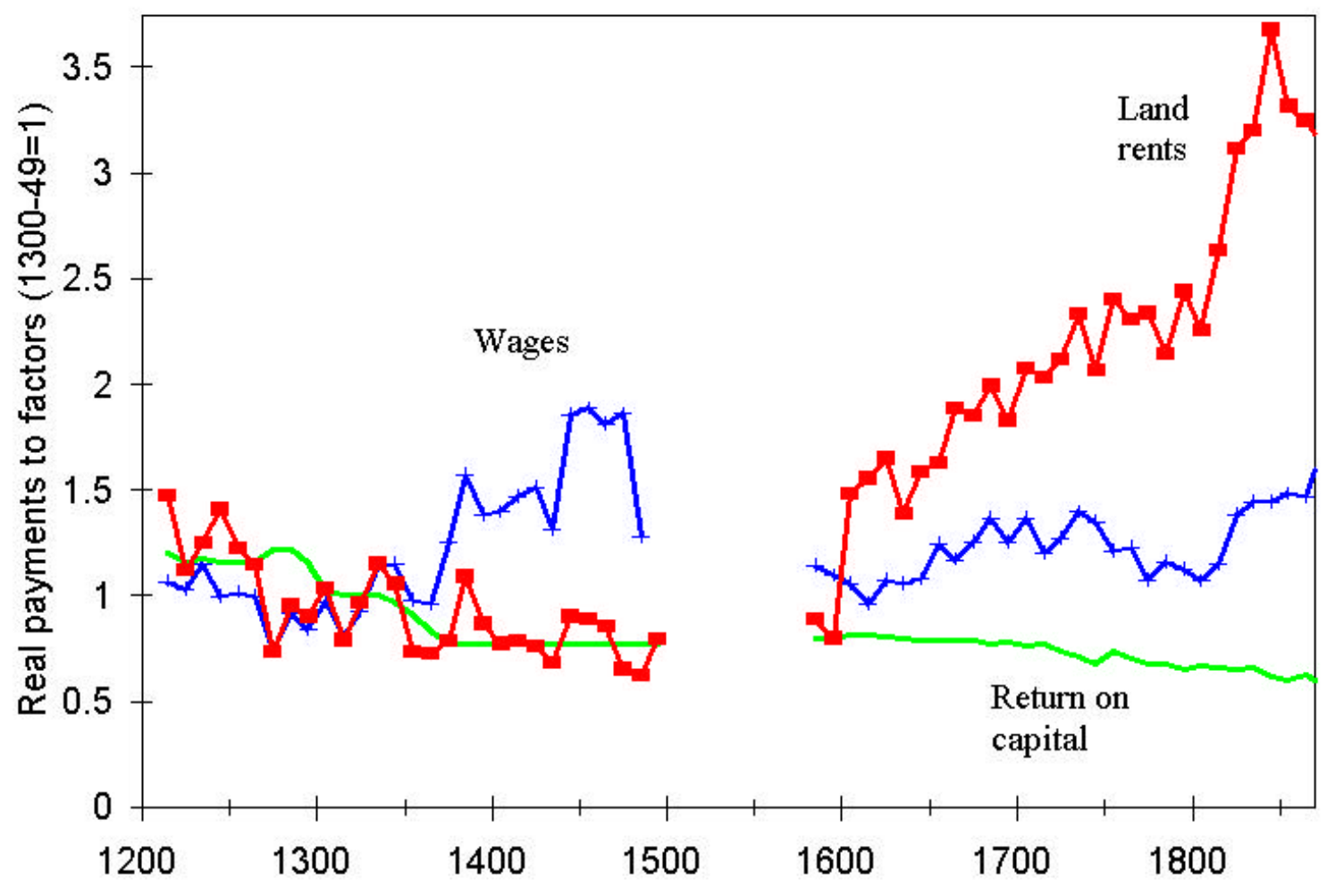


Figure 9: Agricultural Productivity, 1210-1870

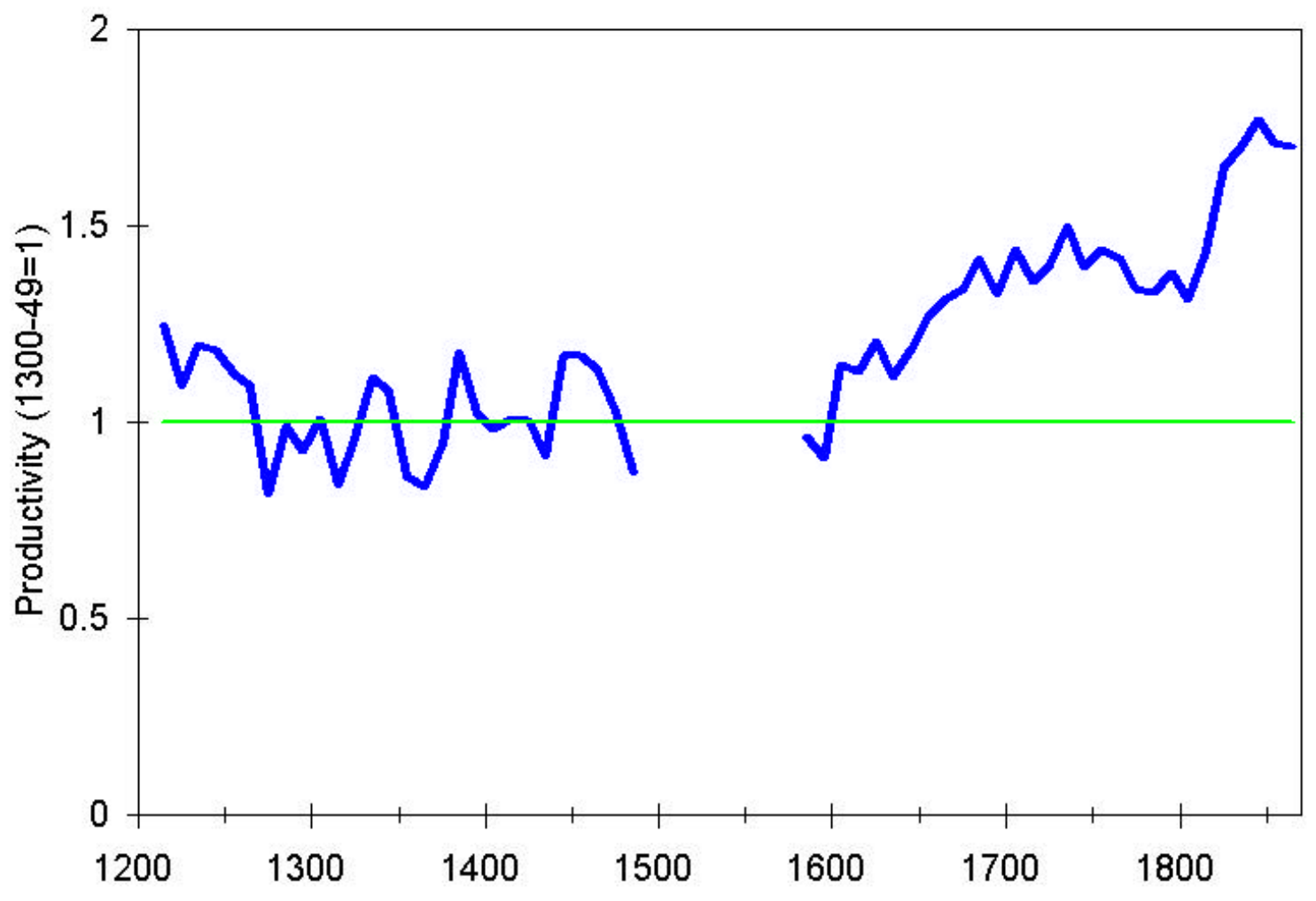




\section{Appendix: The Effect of Population on Wages and Land Rents}

The effect of the fall in population on wages and land rents depends on the degree to which land and capital could be substituted for labor in production. At one extreme suppose that land, labor and capital had to be employed in fixed proportions in agriculture. Suppose each acre of arable involved a given amount of man-days of labor, and produced a technologically fixed amount of output. Then if the amount of labor falls below the amount required to cultivate all the land, and all land is equivalent, some land will be uncultivated, and land rents will fall to zero. In this case the rise in wages will be given by the percentage share of land and wages in farm income before the plague. From other sources I crudely estimate these shares in the years $1300-49$ as $34 \%$ was paid in rent, $50 \%$ in wages, and $16 \%$ for capital. ${ }^{20}$ In this case the effect of the plague would be to raise wages by about $68 \%$, and reduce rents by $100 \%$. Capital would earn the same share as before because we assume that capital earns the same rate of return, and that there is the same amount per acre.

In actual practice it was possible to vary the proportions of labor, land and capital employed in production. Land could be switched from labor intensive arable cultivation to less labor intensive pasture and meadow. On the arable labor could be saved by reducing the number of plowings, by reducing the amount of manure returned to the soil, by not weeding the corn, and by other means. All these measures would reduce the yield, but they implied a saving of labor by using more land. We do not know the exact set of production possibilities facing medieval cultivators. But we can outline a set of possibilities by specifying a production function, which shows how output responds to various inputs of land, labor and capital. One such function is,

\footnotetext{
${ }^{20}$ Clark (1991) estimates the value of output per acre circa 1300-49. The share of rent in output is then estimated from the rent numbers from Table 5 . These imply rents were $34 \%$ of output.
} 


$$
Q=E\left(a K^{\rho}+b L^{\rho}+c T^{\rho}\right)^{1 / \rho}
$$

where $\mathrm{Q}$ is output, $\mathrm{E}$ the level of efficiency, $\mathrm{K}$ is capital, $\mathrm{L}$ labor and $\mathrm{T}$ land. The greater is $\mathrm{E}$ the greater the output per unit of input. $\rho$ indexes the ease with which factors can be recombined to produce output in response to changes in their relative amounts. If ? equals 1 , then land and capital are perfectly substitutable for labor. If ? equals $-\infty$, then no substitution was possible.

$$
\sigma=\frac{1}{1-\rho}
$$

is called the elasticity of substitution. It indicates, for example, what percentage change in the ratio $\mathrm{K} / \mathrm{L}$ will be caused by a $1 \%$ change in the ratio $\mathrm{w} / \mathrm{r}$, where $\mathrm{w}$ is the wage rate, and $\mathrm{r}$ the cost of capital. $\sigma$ will thus range from 0 to $+\infty$.

Let us index efficiency, capital, labor and land quantities in 1300-49 as each being 1, and wages, rents, and the return on capital as again being 1 . In that case $a, b$, and $c$ will be just the shares of capital, labor and land in output in 1300-49: .16, .50, and .34 by assumption. With this specification then the effect of the Black Death on wages and land rents depends only on a, b, c and ?. Thus,

$$
\begin{aligned}
& K_{1}=\left(\frac{b L_{1}^{\rho}+c}{1-a}\right)^{1 / \rho} \\
& s_{1}=K_{1}^{1-\rho} \\
& w_{1}=\left(\frac{K_{1}}{L_{1}}\right)^{1-\rho}
\end{aligned}
$$


Where the subscript " 1 " indicates the level of each variable in 1400. Table 1 shows what the values predicted by these expressions are for capital, wages and rents in 1400 given different values of $\sigma$.

\section{Measuring Efficiency}

The overall efficiency of any economy, or of a sector of an economy, is the output per unit of input. This can be estimated as some kind of weighted average of output per unit of capital, $\mathrm{Q} / \mathrm{K}$, output per worker, $\mathrm{Q} / \mathrm{L}$, and output per acre, $\mathrm{Q} / \mathrm{T}$. The weights will correspond to the importance of each factor in the total costs of production. Thus a simple weighting would be

$$
E=a\left(\frac{Q}{K}\right)+b\left(\frac{Q}{L}\right)+c\left(\frac{Q}{T}\right)
$$

where $\mathrm{a}, \mathrm{b}$, and $\mathrm{c}$ are the shares of capital, labor and land in total costs. But for an economy with a reasonable degree of substitutability between capital, labor and land a better index will be a geometric average. That is

$$
E=\left(\frac{Q}{K}\right)^{a}\left(\frac{Q}{L}\right)^{b}\left(\frac{Q}{T}\right)^{c}
$$

Simply because the value of inputs has to sum up to the value of outputs we can also use as an index of efficiency the weighted average of the real payments to the factors. Thus simply by accounting, 


$$
\begin{aligned}
& p Q=r K+w L+s T \\
& \Rightarrow 1=\left(\frac{r}{p}\right)\left(\frac{K}{Q}\right)+\left(\frac{w}{p}\right)\left(\frac{L}{Q}\right)+\left(\frac{s}{p}\right)\left(\frac{T}{Q}\right)
\end{aligned}
$$

Efficiency will be increasing if on average $\mathrm{K} / \mathrm{Q}, \mathrm{L} / \mathrm{Q}$, and T/Q are falling. But in this case on average $(\mathrm{r} / \mathrm{p}),(\mathrm{w} / \mathrm{p})$, and $(\mathrm{s} / \mathrm{p})$, the real costs per unit of capital, labor and land in terms of the price of output must be rising to maintain the equality above between the value of inputs and of outputs. 


\section{References}

\section{Manuscript Sources from Manorial Accounts:}

Beveridge Collection, LSE. Extracts from manorial accounts.

Battle Abbey: Burnham, Icklesham, Morley (Box H7). Apuldrum, Bright Walton, Bromlain, Brownmarsh, Dengemarsh, Hutton, Lullington, Sampford, Wye (Box H8).

Crowland Abbey: Oakington (Box G10)

Hinderclay (Box G14)

Redgrave (Box G15)

Winchester: Brightwell, Downton, Escher, Farnham, Itchingswell, Ivinghoe, Meon, Nailsbourne, Overton, Staplegrove, Witney, Wargrave, Wycombe (Box A46).

Westminster Abbey: Knightsbridge (Box P1). Aldenham, Launton, Morden, Todenham, Turweston, Westerham (Box P5).

\section{Printed Manorial Sources:}

Coleman, M. Clare. 1984. Downham-in-the-Isle. Woodbridge: Boydell Press.

DeWindt, Edwin Brezette. 1972. Land and People in Holywell-cum-Needingworth. Toronto: Pontifical Institute of Mediaeval Studies.

Davenport, Frances G. 1906. The Economic Development of a Norfolk Manor, 1086-1565. London: Frank Cass.

Gras, Norman Scott Brien. 1930. The Economic and Social History of an English Village:

Crawley, Hampshire, 909-1928. Cambridge, Mass.: Harvard University Press.

Harvey, Barbara. 1977. Westminster Abbey and its Estates in the Middle Ages. Oxford:

Oxford University Press.

Harvey, P. D. A. 1976. The Manorial Records of Cuxham, Oxfordshire, circa 1200-1359.

London: Historical Manuscripts Commission, Joint Publication 23.

Neilson, Nellie. 1898. Economic Conditions on the Manors of Ramsey Abbey. Philadelphia:

Sherman and Co.

Thorner, Christopher Charles. 1988. The Demesne of Rimpton, 938-1412: A Study in

Economic Development. Ph.D. Dissertation, Oxford University.

\section{Printed Cartularies and Deeds}

Bedingfeld, A. L. (ed.) 1966. A Cartulary of Creake Abbey. Norfolk Record Society Publications v. 35. Norwich, Norfolk Record Society.

Blake, E. O. (ed.) 1981. The Cartulary of the Priory of St. Denys near Southampton. Southampton records series ; v. 24-25. Southampton : University Press.

Brown, Vivian. (ed.). 1992. Eye Priory Cartulary and Charters. Suffolk charters, v. 12. Woodbridge, Suffolk: Boydell Press.

Coss, Peter R. 1980. The Langley Cartulary. Publications of the Dugdale Society, v. 32.

Stratford-upon-Avon, Warwickshire : The Shakespeare Centre. 
Coss, Peter R. 1986. The Early Records of Medieval Coventry. Records of Social and Economic History, New Series, 11. London: Oxford University Press.

Denholm-Young, N. 1931. Chartulary of the mediaeval archives of Christ Church. Oxford Historical Society, Publications, v. 92. Oxford: Clarendon Press.

Dunning, Robert W. 1968. The Hylle Cartulary. Somerset Record Society Publications, v. 68. Yeovil Somerset, Somerset Record Office.

Franklin, M. J. 1988. The Cartulary of Daventry Priory. Publications of the Northamptonshire Record Society, v. 35. Northampton : Northamptonshire Record Society.

Harper-Bill, Christopher. 1980-1. Blythburgh Priory Cartulary. Suffolk charters, vs. 2-3.

Woodbridge [Eng.]: Boydell \& Brewer.

Hassall, W. O. 1949. Cartulary of St. Mary Clerkenwell. Camden third series, v. 71. London: Royal Historical Society.

Hockey, S. F. (ed.). 1974. The Beaulieu cartulary. Southampton records series ; vol. 17.

Southampton: University Press.

Hodgett, Gerald A. J. (ed.). 1971. The cartulary of Holy Trinity Aldgate. London Record

Society publications ; v. 7. Leicester, London Record

Society.

London, Vera C. M. 1965. The Cartulary of Canonsleigh Abbey. Devon \& Cornwall Record

Society ; new ser., vol. 8. Torquay: Devonshire Press.

London, Vera C. M. 1979. The Cartulary of Bradenstoke priory. Wiltshire Record Society, v. 35. Devizes, Wiltshire:Wiltshire Record Society.

Rees, Una(ed.). 1975. The Cartulary of Shrewsbury Abbey. Aberystwyth : National Library of

Wales. $2 \mathrm{v}$.

Salter, H. E. 1914-17. A Cartulary of the Hospital of St. John the Baptist. Oxford Historical

Society, vs. 66, 68, 69. Oxford: Clarendon Press.

Salter, H. E. 1929---. Cartulary of Oseney abbey. Oxford Historical Society Series ; v. 89-91, 97-98, 101. Oxford: Clarendon Press.

Salter, H. E. 1930. The Boarstall Cartulary. Oxford Historical Society Series, v. 88. Oxford: Clarendon Press.

Saltman, Avrom. 1967. The Cartulary of Dale Abbey. Historical Manuscripts Commission ; Joint Publication 11. London, H.M.S.O..

Timson, R. T. (ed.) 1973. The cartulary of Blyth Priory. Royal Commission on Historical Manuscripts, Joint Publication 17. London, H.M.S.O..

Watkin, Aelred. 1952. The great chartulary of Glastonbury, Vol. 2. Somerset Record Society, v. 63. Frome, Butler \& Tanner.

Wigram, Spencer R. 1895-6. The cartulary of the Monastery of St. Frideswide at Oxford. Oxford Historical Society Series, vols. 28, 31. Oxford: Clarendon Press.

Woodcock, Audrey M. 1956. Cartulary of St. Gregory's Priory, Canterbury. Camden third series, v. 88. London: Royal Historical Society.

\section{Other}

Bean, J. M. W. 1991. "Landlords," in Edward Miller (ed.), The Agrarian History of England and Wales, Volume III, 1348-1500, 526-586. Cambridge: Cambridge University Press.

Britnell, R. H. 1993. 
Cameron, Rondo. 1989. A Concise Economic History of the World. Oxford: Oxford University Press.

Campbell, Bruce M. S., James Galloway, and Margaret Murphy. 1992. "Rural Land Use in the Metropolitan Hinterland, 1270-1339: the Evidence of Inquisitiones Post Mortem." Agricultural History Review, 40(1): 1-22.

Clark, Gregory. 1988. "The Cost of Capital and Medieval Agricultural Technique,"

Explorations in Economic History, 25 (July), 265-294.

Clark, Gregory. 1991. "Labour Productivity in English Agriculture, 1300-1860," in B.M.S.

Campbell and Mark Overton, Agricultural Productivity in the European Past. Manchester:

Manchester University Press, 211-235.

Clark, Gregory. 1991. "Yields per Acre in English Agriculture 1266-1860: Evidence from

Payments to Labour," Economic History Review, (August 1991), 445-460.

Clark, Gregory. 1992. "The Economics of Exhaustion, the Postan Thesis, and the Agricultural

Revolution," Journal of Economic History, 52 (March, 1992), 61-84.

"Land Hunger: Land as a Commodity and as a Status Good in England, 1500-1914,"

Explorations in Economic History, 35(1) (Jan., 1998), 59-82.

Davis, G. R. C. 1958. Medieval Cartularies of Great Britain: a Short Catalogue. London.

Farmer, D. L. 1988. "Prices and wages," in H. E. Hallam (ed.), The Agrarian History of

England and Wales, Vol. II, 1042-1350, 716-817. Cambridge: Cambridge University Press.

Farmer, D. L. 1991. "Prices and Wages, 1350-1500," in Edward Miller (ed.), The Agrarian

History of England and Wales, Vol. III, 1348-1500, 431-525. Cambridge: Cambridge University

Press.

Foulds, Trevor. 1987. "Medieval Cartularies," Archives, 18 (April), pp. 3-35.

Hallam, H. E. 1988. "Population Movements in England, 1086-1350: Postcript," in H. E.

Hallam (ed.), The Agrarian History of England and Wales, Vol. 2, 1042-1350, p. 536-593.

Cambridge: Cambridge University Press.

Harvey, P. D. A. 1984. Manorial Records. London: British Record Association.

Hatcher, John. 1977. Plague, Population, and the English Economy, 1348-1530.

Poos, L. R. 1991. A Rural Society After the Black Death: Essex, 1350-1525. Cambridge:

Cambridge University Press.

Postan, M. M. 1938.

Razi, Zvi. 1980. Life, Marriage and Death in a Medieval Parish: Economy, Society and Demography in Halesowen, 1270-1400. Cambridge: Cambridge University Press.

Rogers, J. E. Thorold. 1866. A History of Agriculture and Prices in England, Vol 2. London. Thrupp, Sylvia L. 1948. The Merchant Class of Medieval London. Ann Arbor: University of Michigan. 